\title{
Empirical Juridistic Review Toward Non Active Cooperation in Lombok Barat District
}

\author{
Aslihan Muzaani $^{1} \quad$ Muhammad Sood $^{2} \quad$ Kurniaawan $^{2}$ \\ 1.Graduate Program Student in Notary, Faculty of Law, Mataram University, Indonesia \\ 2.Lecturer of Faculty of Law, Mataram University, Indonesia
}

\begin{abstract}
The healthy and ideal cooperatives are cooperatives that are run in accordance with the principles and values of cooperatives. However, the development of cooperatives in Indonesia currently shows that cooperatives do not yet have the ability to carry out their roles effectively. With the ineffectiveness of the cooperative business results in the performance of the cooperative can not run well, the existence of an inactive cooperative in West Lombok regency is a form of cooperation that is not in accordance with the purpose of establishing a cooperative and is one of the problems at the moment. The purpose of the research is to know and analyze the causes of inactive cooperatives in West Lombok Regency, as well as to find out and analyze the role of the government as a regulator in solving the problems of inactive cooperatives in West Lombok Regency. Research using empirical research. The approach used is the statutory approach, conceptual approach, and sociological approach. The analysis used is qualitative-descriptive analysis. Factors causing the existence of inactive cooperatives in West Lombok Regency can be caused by internal and external factors, namely: Cooperatives have never organized Members' meeting, cooperative management, no cooperative activities, absence of SOPs in cooperative management, lack of quality competencies from cooperative human resources managers and management. With this condition, the cooperative's operations are not going well; mindset of the founders of cooperatives, the limited capital owned by the cooperative concerned, causing a setback from the cooperative business so that the cooperative becomes inactive. To reduce the increasing number of cooperatives that are not active in West Lombok Regency, the government through the Department of Cooperatives and Small and Medium Enterprises conducts a training and supervision program on cooperative activities in West Lombok Regency through Education and training programs, and supervision of cooperatives for and against the managers, managers, employees, members of the examining body, cooperative cadres and Field Cooperative Consultation Officers.
\end{abstract}

Keywords: Inactive cooperatives, establishment

DOI: $10.7176 / \mathrm{JLPG} / 98-05$

Publication date:June 30th 2020

\section{Introduction}

Ideally a healthy cooperative is a cooperative that is run in accordance with the principles and values of the cooperative. Cooperative health is a condition or condition of a cooperative declared healthy, healthy enough, less healthy, unhealthy and very unhealthy. However, the development of cooperatives in Indonesia currently shows that cooperatives do not yet have the ability to carry out their roles effectively.

Inactive cooperatives are cooperatives that make financial reports but never hold a Member Meeting even though they still have members. The number of cooperatives in West Lombok is 529 cooperatives. While those who held the Annual Member Meeting (RAT) in 2014 were 105 cooperatives, in 2015132 cooperatives, 130 cooperatives in 2016, 120 cooperatives in 2017, and in 2018125 cooperatives that implemented RATs. If you look at the data from year to year, only $50 \%$ of the 502 cooperatives in West Lombok are said to be healthy while the remaining $75 \%$ are due to not holding annual member meetings. So it can be concluded about 377 cooperatives in West Lombok Regency that are unhealthy or inactive. The existence of inactive or inactive cooperatives in an area, for example the West Lombok regency is a form of cooperation that is not in accordance with the purpose of establishing a cooperative and is one of the problems at this time. Actions taken by the founder of the Cooperative who are not active in West Lombok Regency, are regulated in Act Number 25 of 1992 concerning Cooperatives.

By looking at the existence of inactive cooperatives in West Lombok, it can be said that there has been a violation of cooperative law committed by several persons who may only utilize the legal entity status of a cooperative only as a means of obtaining assistance only without the management of funds that should and should be carried out by a cooperative institutions, because basically according to the law in Indonesia every cooperative that is formed must get guidance from the government, by seeing the growth in the number of inactive cooperatives in West Lombok Regency, of course this will be very worrying, where this is in line resulting in the large number of cooperative law violations which occurred in Indonesia especially in West Lombok Regency. Based on the description above, a number of problems can be formulated as follows: What causes the emergence of inactive cooperatives in West Lombok Regency?, What is the role of the government as regulator in solving the problems of inactive cooperatives in West Lombok Regency?.

The purpose of this study is to find out and analyze the causes of inactive cooperatives in West Lombok 
Regency, as well as to find out and analyze the role of the government as a regulator in solving the problems of inactive cooperatives in West Lombok Regency. This research uses empirical research by making field data as primary data. The approach used is the statutory approach, conceptual approach, and sociological approach. Secondary data collection techniques are data collected by document study techniques by collecting and studying sources such as literature, books, scientific articles, research results and legislation relating to the subject matter then Analysis used is analysis Qualitative-descriptive analysis that is based on the type and purpose of research and the nature of the data collected, then checked and re-evaluated the accuracy of the data in accordance with the results of field analysis.

\section{Reserach Method}

The approach used in this study is the statutory approach, conceptual approach, and sociological approach. The analysis used is qualitative-descriptive analysis. Factors causing the existence of inactive cooperatives in West Lombok Regency can be caused by internal and external factors, namely: Cooperatives have never organized Members' meeting, cooperative management, no cooperative activities, absence of SOPs in cooperative management, lack of quality competencies from cooperative human resources managers and management.

\section{Discussion}

\section{The Causes Of Emergency Cooperation Is Not Active In West Lombok District}

West Lombok Regency as part of the administrative area in NTB Province, also has active and inactive cooperatives. There are 296 cooperatives active in Lobar. While inactive cooperatives were 207 cooperatives. There are 124 cooperatives that have done RATs.

It was noted that of the 503 cooperatives, 207 cooperatives suffered near-death, in other words, could not function as they should. This was also justified by the Head of the West Lombok Regency Cooperative and SME Office, "Nearly $41 \%$ of them or as many as 207 cooperatives in West Lombok Regency were declared inactive". If the percentage of inactive cooperatives in the West Lombok regency city continues to increase, it is not impossible that in the future it will affect the economy of the local community as well. Therefore, both the community, members of the organization and government / cooperative services must be more sensitive to the problems of this cooperative.

Going well or whether an organization's performance is influenced by several factors. According to Soesilo in Hessel Nogi the performance of an organization is influenced by the following factors:

1. Organizational structure as internal relationships related to functions that carry out organizational activities.

2. Management policies, in the form of an organization's vision and mission.

3. Human resources, related to the quality of employees to work and work optimally.

4. Management information system, which is related to managing a data base to be used to enhance organizational performance.

5. Facilities and infrastructure owned, which are related to the use of technology for the organization of the organization in every activity of the organization.

In addition, there are still many factors that can affect organizational performance, as stated by Ruky in Hessel Nogi identifying factors that directly influence the level of achievement of organizational performance as follows:

1. Technology that includes work equipment and work methods used to produce products and services produced by the organization, the more quality the technology is used, the higher the performance of the organization.

2. The quality of inputs or materials used by the organization, which consists of:

a. The quality of the physical environment which includes work safety, room arrangement, and cleanliness.

b. Organizational culture as a pattern of behavior and work patterns that exist in the organization concerned

c. Leadership as an effort to control members of the organization to work in accordance with the standards and goals of the organization.

d. Human resource management which includes aspects of compensation, rewards, promotions, and others.

According Atmosoeprapto, stated that organizational performance is influenced by internal factors and external factors, further these two factors are described as follows:

1. External factors, which consist of:

a. Political factors, namely matters relating to the balance of state power that affect security and order, will affect the peace of the organization to work optimally.

b. Economic factors, namely the level of economic development that affects the level of community income as a purchasing power to drive other sectors as a larger economic system.

c. Social factors, namely the orientation of values that develop in society, which affect their views of the work ethic needed for improving organizational performance.

2. Internal factors, which consist of:

a. Organizational goals, namely what you want to achieve and what you want produced by an organization;

b. Organizational structure, as a result of the design of functions to be carried out by organizational units with 
existing formal structures;

c. Human resources, namely the quality and management of members of the organization as the driving force for the overall organizational net;

d. Organizational Culture, namely the style and identity of an organization in a standard work pattern and becomes the image of the organization concerned.

So in my opinion there are a number of things that underlie why cooperatives become inactive cooperatives, namely:

1. The Cooperative never holds a Member Meeting.

Members' Meeting is one of the tools of cooperative organization equipment, so that if a cooperative does not hold a Member Meeting, it means that one of the tools of the cooperative organization concerned is not functioning, although normatively in its Articles of Association / Bylaws the existence and role of the Member Meeting is recognized.

2. Cooperatives cannot carry out cooperative activities, be they organizational, management, or business, so that the three things do not work as they should.

3. Problems from the (internal) cooperative concerned, namely:

a. Lack of understanding among supervisors, members and especially the management of cooperatives regarding cooperatives. This misunderstanding starts from the understanding and function of the cooperative business entity, the lack of understanding in managing and managing the cooperative, and the absence of Standard of Procedure (SOP) in cooperative management.

b. Lack of quality competencies of human resources managers and management of cooperatives. With these conditions resulted in cooperative operations to be not going well.

4. The mindset of the founders of cooperatives, namely the tendency that the initial establishment of cooperative business entities as a forum or a forum for friendship and more of a community nature. So it is not a business entity that results in not running a cooperative business with professional business. In addition, because cooperatives are often underestimated as a side business that is not profit oriented makes the implementation of cooperative business is not optimal.

5. Cooperative capital. As a cooperative business entity, it certainly requires capital so that it can run its economic business. So that the capital factor in the cooperative business is one of the tools that will determine the cooperative's progression. However, with the limited capital owned by the cooperative concerned, causing a setback from the cooperative business so that the cooperative becomes inactive.

6. Competition between business entities.

7. The existence of cooperatives is dominated by the types of savings and loan cooperatives. This was based on the thought of the ease in legal relations of borrowing and borrowing funds from savings and loan cooperatives compared to banks. However, with the increasing ease in lending funds to banks, the competitiveness of these business opportunities has decreased, so the cooperative's performance becomes inactive.

From these factors, it is known that, if the factors that have the most dominant influence in an organization's performance are internal factors (factors originating from within the organization) and external factors (factors originating from outside the organization). Organizational performance is a picture of the work of the organization in achieving its objectives which of course will be affected by the resources owned by the organization. These resources can be physical such as human or non-physical resources such as regulations, information, and policies, so as to better understand the factors that can affect an organization's performance. Keep in mind, differences in resources and internal factors and external factors of each organization, this will cause differences in the results of the assessment and achievement of each organization's performance.

\section{The Role Of The Government As A Regulaterial Regulation To Solve The Problem Of The Active Cooperation In West Lombok District}

In accordance with West Lombok Regency Regulations Number 67 Year 2016 concerning Details of Duties, Functions and Work Procedures of the West Lombok Regency Small and Medium Enterprises Cooperative Office is an element of implementing regional autonomy, led by the head of the office which is located below and is responsible to the Regent through the Regional Secretary.

The cooperative service programs in cooperative institutional development policies and cooperative business development in West Lombok Regency are:

1. Cooperative education and training for managers, managers, employees, members of the examining body, cooperative cadres and Field Cooperative Consultation Officers (PKKL)

2. Guidance and consultation to improve organizational order, especially in organizing the Annual Member Meeting (RAT)

3. Enhancing cooperative organization and management capabilities

4. Increase the ability to apply the cooperative accounting system; 
5. Enhancing the internal supervision capabilities of primary cooperatives;

6. Increase the active participation of members;

7. Provision of business information;

8. Implementation of work practices or apprenticeship activities for Village Unit Cooperative business managers;

9. Conducting comparative study activities for cooperative managers to broaden their insights and knowledge;

10. Counseling to increase the productivity of members' businesses through a group approach;

11. Provision of cooperative business facilities in the context of increasing the range and quality of cooperative services to members and surrounding communities in disadvantaged, transmigration, border and isolated areas.

The results achieved after the implementation of these programs by the government in the district of West Lombok are:

1. Program of Supervision Activities carried out by:

a. The business development system development program for micro small and medium businesses through the activities of fostering supervision and evaluation of health of Ksp / USP cooperatives, the achievement of this activity is that the government succeeded in re-establishing 11 cooperatives in West Lombok regency;

b. The business development system development program for micro small and medium businesses through monitoring, evaluation and reporting activities, the results achieved are the creation of cooperatives that comply with the rules and the completion of the dissolution of as many as 40 cooperatives;

c. The cooperative institutional quality program through the activities of fostering supervision and evaluation of outstanding cooperatives results in the achievement of 10 quality cooperatives;

d. Improving the quality of human resources of cooperatives through cooperative training and supervisory training activities, the results achieved are the availability of 60 cooperative supervisors who act as trained cooperative managers.

2. Program activities in the field of cooperative development carried out by:

a. Program for improving the quality of cooperative institutions through activities to improve and develop cooperative networks of cooperative business cooperatives with the aim that management / supervisors and members of cooperatives have been verified to be demonstration plots of activities in the area of West Lombok Regency;

b. Cooperative institutional quality improvement program through cooperative accounting training activities in the pioneering activities of the application of simple technology / modern management in the type of cooperative business with the aim that it is aimed at cooperative officials invited.

3. The program of activities in the field of cooperative financing facilitation and the activities are carried out through information dissemination programs to support capital provision, aligning the utilization of government facilitation for small and medium enterprises and cooperatives, monitoring the management of the use of government funds for UMKM, network development and entrepreneurship for Ksp / USP cooperatives, institutional development and control microfinance $(\mathrm{km})$, in this activity the government provides assistance in channeling financing to several cooperatives that need funding assistance while continuing to provide guidance related to monitoring the management of the use of government funds for small and medium businesses. 4. Field activities program, this activity is in the form of assistance for welding workshop equipment and people's salt processing equipment to several cooperatives that carry out their business activities in the related fields.

Much has been done by the government for cooperatives, but the role of this government cannot be realized only with the government alone, but the role of the community is also very necessary so that what the government plans can be realized. The government does this also for its people to improve their lives, reduce unemployment, improve living standards. After the community and the government work together to carry out their respective roles there will be no more obstacles to the development of cooperatives, with the role of cooperatives that look like nothing but meaningless roles that will turn into meaningful ones. In this case what was once a cooperative is considered to be one-sided and does not have a large role for the state, it will change to have a large role if the role of the government and society for the cooperative is carried out.

\section{Conclusion}

The results of the study concluded that the factors causing the existence of inactive cooperatives in West Lombok Regency could be caused by internal and external factors, namely: the Cooperative never held a Member Meeting, the cooperative management did not conduct cooperative activities, the absence of Standard of Procedure (SOP) in cooperative management, the lack of quality competencies of human resources managers and management of cooperatives. With this condition, the cooperative's operations are not going well; mindset of the founders of cooperatives, the limited capital owned by the cooperative concerned, causing a setback from the cooperative business so that the cooperative becomes inactive. Then To suppress the increasing number of cooperatives that 
are not active in West Lombok Regency, the government through the Department of Cooperatives and Small and Medium Enterprises conducts a training and supervision program on cooperative activities in West Lombok Regency through Education and training programs, and supervision of cooperatives for and against managers, managers, employees, members of the examining body, cadres of cooperatives and Field Cooperative Consultative Officers, where the programs have succeeded in re-observing 11 cooperatives that are barely active, dissolving 40 inactive cooperatives, achieving the target of 10 quality cooperatives that can competing nationally and the availability of 60 cooperative supervisors who act as trained cooperative managers.

The suggestion that the writer can give is that the management of cooperatives in carrying out cooperative business activities are expected to always be active in making adjustments to the current era of the industrial revolution 4.0 so as not to be left behind through the use of technology and information which is currently growing, so that with the understanding and application that is both in the cooperative business are expected to advance the cooperative business so as to suppress the increase in the number of inactive cooperatives, and the Government is expected to always encourage the independence of cooperatives and SMEs through capital support and infrastructure suggestions to increase productivity, added value, quality of work and competitiveness of cooperatives and MSMEs, especially to improve in training on the use of technology so that cooperatives can still compete with the increasingly rapid advancement of the times.

\section{Refferences}

A.A. Anwar Prabu Mangkunegara, Manajemen Sumber Daya Manusia, PT. Remaja Rosdakarya, Bandung, 2008. Ali Rido, Badan Hukum dan Kedudukan Badan Hukum Perseroan, Perkumpulan, Koperasi, Yayasan, Wakaf, PT. Alumni, Jakarta, 2012.

Andjar Pachta W, dkk, Hukum Koperasi Indonesia, Kecana, Jakarta, 2012.

Arifin Sitio dan Tamba Halomoan, Koperasi : Teori dan Praktik, Erlangga, Jakarta, 2001.

Hukum Koperasi Indonesia: Pemahaman, Regulasi, Pendidikan, dan Modal Usaha, Cet. Ke-2, Kencana, Jakarta, 2007.

Budi Untung, Hukum Koperasi dan Peran Notaris Indonesia, cet.1, Andi, Yogyakarta, 2005. Reformasi Yayasan, Andi Offset, Yogyakarta, 2002.

Buku Pedoman Pegawai Kementerian Koperasi dan UMKN tahun 2017.

Dewa Gede Atmadja, Hukum Konstitusi, Problematik Konstitusi Indonesia Sesudah Perubahan UUD NRI 1945, Edisi Revisi, Setara Press, Malang, 2010.

Muhammad Firdaus dan Agus Edhi Susanto, Perkoperasian, Ghalia Indonesia. Bogor, 2004. 2002. \& Agus Edhi Susanto, Perkoperasian Sejarah, Teori, dan Praktek: Ghalia Indonesia, Jakarta,

Hendrojogi. Koperasi, Asas-asas, Teori, dan Praktik. RajaGrafindo Persada, Jakarta, 2007.

Panji Anoraga dan Ninik Widayanti, Dinamika Koperasi, PT Asdi Mahasatya, Jakarta, 2003.

Peter Mahmud Marzuki, Pengantar Ilmu Hukum, Kencana Prenada Media Group, Jakarta, 2008.

Sudarsono dan Edilius, Koperasi dalam Teori dan Praktek, Cet. Ke-5, Renika Cipta, Jakarta, 2010.

Suhendi H Hedi, Fiqih Muamalah: Gunung Djati Press, Bandung, 1997.

Soerjono Soekanto, Faktor-faktor Yang Mempengaruhi Penegakan Hukum, UI Pres, Jakarta, 1983.

Soerjono Soekanto. Efektivitas Hukum dan Penerapan Sanksi. Bandung. CV. Ramadja Karya. 1988.

Indonesia, Undang-Undang Dasar Negara Republik Indonesia 1945.

Indonesia, Kitab Undang-Undang Hukum Perdata ( KUHPER ).

Indonesia, Undang-Undang Nomor 2 Tahun 2014 tentang PerubahanAtas Undang-Undang Nomor 30 Tahun 2004 tentang JabatanNotaris. (Tambahan Lembaran Negara NO. 5491).

Indonesia, Undang-Undang Nomor 25 Tahun 1992 tentangPerkoperasian (Tambahan Lembaran Negara NO. 3052).Indonesia, Peraturan Pemerintah Nomor 4 Tahun 1994 tentang Persyaratan dan Tata Cara Pendirian dan Perubahan Anggaran Dasar Koperasi

Peraturan Pemerintah Nomor 17 Tahun 1994 tentang Pembubaran Koperasi Oleh Pemerintah.

Peraturan Menteri Koperasi dan Usaha Kecil dan Menengah RepublikIndonesia Nomor 16/Per/M.KUKM/IX/2015 tentang UsahaSimpan Pinjam dan pembiayaan Syariah (Berita NegaraRepublik Indonesia Tahun 2015 Nomor 1495).

Peraturan Menteri Koperasi dan Usaha Kecil dan Menengah RepublikIndonesia Nomor 15/Per/M.KUKM/IX/2015 tentang UsahaSimpan Pinjam Oleh Koperasi (Berita Negara RepublikIndonesia Tahun 2015 Nomor 1494).

Peraturan Menteri Koperasi dan Usaha Kecil dan Menengah RepublikIndonesian Nomor 10/Per/M.KUKM/IX/2015 tentang Kelembagaan Koperasi (Berita Negara Republik IndonesiaTahun 2015 Nomor 1489).

La Ode Angga, Tanggung Jawab Pembentukan Lembaga Penyelesaian Sengketa Lingkungan Hidup Diluar Pengadilan (Non Litigasi) Yang Bersifat Mandiri dan Propesional, Jurnal IUS, 2 Agustus 2018.

Patrisia Shintasari, Analisis Tanggung Jawab Koperasi Terhadap Adanya Kegiatan Modal Penyertaan Di 
Koperasi, Tesis Fakultas Ekonomi Universitas Indonesia, 2013.

Widiastuti, Masalah Hukum Koperasi Berbadan Hukum yang Berstatus Pasif dan Beku,Wacana Hukum Volume VII No. 2, (Oktober 2008). 